\title{
The Ecological Situation in the Russian Arctic Permafrost Zone
}

\author{
Sergei Petrov ${ }^{1, *}$, Natali Mamaeva ${ }^{2}$, Maxim Gabdullin ${ }^{1}$ and Alexey $\mathrm{Kraev}^{3}$ \\ ${ }^{1}$ Tyumen Scientific Center, SB RAS, Tyumen, 625026, Russia \\ ${ }^{2}$ Tyumen Scientific Center, SB RAS, IUT, Tyumen, 625026, Russia \\ ${ }^{3}$ Industrial University of Tyumen, 625001 Volodarskogo str. 38, Tyumen, Russia
}

\begin{abstract}
The paper describes innovative approaches to ensure environmental safety in the production of hydrocarbon material in a permafrost zone. Studies the anthropogenic environmental factors, climatic and geographical and geological conditions of Purovskiy district of Yamalo-Nenets Autonomous Area (YaNAO). We consider the chemical characteristics of wastewater discharged into surface water objects, polluting emissions into the atmosphere. The conclusions of the environmental situation in Purovskiy and Ustpurovsk-Tazovskiy permafrost areas. Calculate the concentration of pollutants in the control section of the water object and the maximum ground-level concentrations of pollutants in the atmospheric air. The conclusions about the exceeding the maximum permissible concentration (MPC) in the atmospheric air for solids, carbon monoxide, nitrogen dioxide. Was examined the climatic conditions of the Far North. Correlational analysis was performed between human factors and temperature conditions of the northern territories, as well as between the climate and natural features cryological and disturbed permafrost soils.
\end{abstract}

\section{Introduction}

Russian Arctic - the most important and many-sided area, which is characterized by a combination of extreme cold temperatures originality helio geomagnetic background, unusual light conditions with periodic shortage of solar radiation, shifts biorhythmological processes and has huge reserves of hydrocarbons $[1,2]$. Data on the hydrocarbon reserves of the Arctic published periodically in different countries of the world. However, their estimates vary considerably. According to UN statistics, the Arctic oil proven reserves amount to 100 billion tons, gas - 50 trln.m3. According to the calculations of a number of industry analysts, potential geological reserves of hydrocarbons in the Arctic are estimated at 200 billion tons of oil and $400 \operatorname{trln} . \mathrm{m} 3$ gas [3].

US Geological Survey Experts (USGS) believe that the Arctic is a fifth of the unexplored recoverable reserves of oil and natural gas. Potential reserves of oil in the region - 90 billion barrels, gas -47.3 trln.m3, gas condensate - 44 billion barrels $[4,5]$.

\footnotetext{
*Corresponding author: tumiki@mail.ru
} 
The largest total reserves of the Arctic, according to the USGS, concentrated in the West Siberian Basin - 3.6 billion barrels. of oil, 18.4 trln.m3 of gas and 20 billion. barrels. of gas condensate. This is followed by the Arctic shelf of Alaska (29 billion barrels of oil, gas - 6.1 trln.m3 and 5 billion barrels of gas condensate), The third place - the eastern part of the Barents Sea shelf ( 7.4 billion barrels of oil, 8.97 trln.m3 of gas and 1.4 billion. barrels. of gas condensate) $[6,7,8]$. Oil industry at risk of exposure to the environment ranked third among the 130 branches of modern production. Mining of hydrocarbons accompanied by a significant damage to the environment. Practically none of the existing oil and gas fields in Russia, does not apply to so-called "waste-free production". This is due to the imperfection of production technology, its disturbances, poor quality or deterioration of the technological equipment, natural features of oil and gas regions of the Arctic zone. Arctic landscapes are characterized by low resistance to anthropogenic influences. The more intense fluids removal is carried out, the more active is the formation of technogenic streams of various substances in the environment that have a negative impact on the atmosphere, the hydrosphere, soil, subsoil $[9,10]$. Currently, environmental studies in the Russian Arctic, in particular Purovskiy region of Yamalo-Nenets Autonomous Area (YaNAO), are relevant.

\section{Materials and methods}

Studied anthropogenic factors, climatic geographical and geological environmental conditions of Purovskiy district YaNAO (settlement Sumburgh and Tarko-Sale, which according to the zoning of the permafrost zone belong to the North-Kharasavey Novy Urengoy subzone Ustpurovsk-Tazovskiy region and Central region Igarka-Numtinskoy subzone Purovskiy area) [11]. Sumburgh is located in the Urengoy oil and gas area with a high density of initial potential resources of hydrocarbons. Near the village is located Samburgskoye field gas condensate and 11 oil deposits (6 condensate, 2 oil and 3 oil with gas condensate) [12]. City Tarko-Sale is in the Pur-Tazovsky oil and gas area, which is characterized by high hydrocarbon resources. Near the city is a large of the East Tarkosalinskoye field gas condensate and oil with 17 deposits of hydrocarbons ( 1 gas, 8 gas condensate, 8 oil with gas condensate) [12]. To study the anthropogenic factors analyzed the quality of surface water objects: chemical characteristics of wastewater discharged in superficial water objects for different pollutants. Considered air pollution data in permafrost areas: emissions of pollutants into the atmosphere $[13,14,15]$. Been calculated concentration of pollutants in the water object control section (Cc.s. $\mathrm{mg} / \mathrm{l})$ and maximum ground concentration of harmful substances in the air (Cmax, $\mathrm{mg} / \mathrm{m} 3)$ [16, 17]. The calculation of the dispersion of surface concentrations of pollutants in the atmospheric air was made taking into account the physical and geographical and meteorological environmental conditions with OND-86 «Method of calculating the concentration in the atmospheric air of harmful substances in emissions of enterprises» [18] and software system unified program for calculating pollution of atmosphere (UPCPA) "Eco Centre» [19]. To study the climatic conditions are analyzed temperature characteristics: annual air temperature, average air temperature in the 13 p.m., the average minimum, absolute minimum temperature, maximum temperature and the amplitude of temperature vibrations of air per year. Climatic data were obtained from the Climate directories [20], as well as www.meteo.infospase.ru site [21]. In the study cryological conditions (power and humidity seasonally thawed layer) used data from the Institute of Earth Cryosphere of SB RAS [22].

Qualitative and quantitative traits subjected to statistical analysis using the «SPSS 11,5 for Windows» program. Been studied distribution pattern of the studied traits. When a Gaussian distribution used the following statistical parameters: the average (arithmetic mean, median, mode), variance and its derivative. Were compared significant difference 
(similarity) between the statistical characteristics by the criterion of the Student. The significance of differences between mean values calculated by standard error of the arithmetic mean value. In the absence of normal distribution using non-parametric methods of comparing two samples with the calculation of the pair Wilcoxona criterion, Spearman rank correlation coefficient.

\section{Ecological analysis of Cryolithozone of Purovskiy district of Yamalo-Nenets Autonomous Area}

\subsection{Anthropogenic pollution of the permafrost zone of Purovskiy district of Yamalo-Nenets Autonomous Area}

Technogenic impact on cryolithozone become particularly dangerous in recent decades. The intensity of air pollution emissions by pollutants from stationary and mobile sources, the quality of water objects are the main environmental factors. They affect the physical well-being of the population [9,23]. Table 1 examined chemical characteristics of the waste into the air and water emissions Ustpurovsk-Tazovskiy and Purovsky permafrost areas. It was found that in the organized discharge of industrial wastewater in superficial water objects in the Purovskiy geocryological area compared to with Ustpurovsk-Tazovskiy geocryological region greater concentration of pollutants: iron (1.57 \pm 0.17 tons and $0.37 \pm$ 0.11 tonnes respectively at $\mathrm{p}<0.001)$, chloride $(0.02 \pm 0.004$ ths. tons and $0.01 \pm 0.002$ ths. tons, respectively, at $\mathrm{p}<0.05)$, ammonia nitrogen $(10.89 \pm 1.66$ tons and $1.01 \pm 0.17$ tonnes respectively at $\mathrm{p}<0.001)$. Significant differences in other pollutants discharged into superficial water objects were not found.

Table 1. Chemical characterization wastewater and air emissions.

\begin{tabular}{llll}
\hline № & Substance name & Ustpurovsk-Tazovskiy & Purovskiy \\
\hline 1. & Wastewater & \\
1.1. & Synthetic surfactants, [tons] & $0.04 \pm 0.01$ & $0.07 \pm 0.02$ \\
1.2. & Total phosphorus, [tons] & $0.25 \pm 0.05$ & $0.37 \pm 0.09$ \\
3. & Iron, [tons] & $0.37 \pm 0.11$ & $1.57 \pm 0.17 * *$ \\
1.4. & Sulfates, [ths. tons] & $0.01 \pm 0.001$ & $0.02 \pm 0.01$ \\
1.5. & Chloride, [ths. tons] & $0.01 \pm 0.002$ & $0.02 \pm 0.004^{*}$ \\
1.6. & Nitrogen ammonium, [tons] & $1.01 \pm 0.17$ & $10.89 \pm 1.66^{* *}$ \\
1.7. & Nitrates, [tons] & $7.55 \pm 2.13$ & $5.22 \pm 2.55$ \\
1.8. & Nitrites, [tons] & $0.11 \pm 0.02$ & $0.77 \pm 0.45$ \\
2. & Emissions to air & & \\
2.1. & Total of them, [tons]: & $8609.35 \pm 1574.71$ & $395978.10 \pm 34298.67 * *$ \\
2.1.1. & Solid, [tons] & $104.88 \pm 15.14$ & $14210.65 \pm 676.63^{* *}$ \\
2.1.2. & Gaseous and liquid, including, [tons]: & $8504.53 \pm 1576.76$ & $381767.50 \pm 31927.93^{* *}$ \\
2.1.2.1. & Sulphur dioxide, [tons] & $82.71 \pm 11.54$ & $929.47 \pm 39.84 * *$ \\
2.1.2.2. & Carbon monoxide, [tons] & $4023.41 \pm 693.40$ & $215444.20 \pm 24814.86^{* *}$ \\
2.1.2.3. & Nitrogen oxides, [tons] & $1334.06 \pm 235.74$ & $23789.00 \pm 1161.49 * *$ \\
2.1.2.4. & Hydrocarbons (no VOCs), [tons] & $2972.47 \pm 692.52$ & $136530.20 \pm 14237.04^{* *}$ \\
2.1.2.5. & Volatile organic compounds (VOCs), [tons] & $124.45 \pm 43.55$ & $5292.12 \pm 732.57^{* *}$ \\
\hline
\end{tabular}

\footnotetext{
* - reliability of difference $(*-\mathrm{p}<0.05 ; * *-\mathrm{p}<0.001)$.
} 
Emissions of solid pollutants in the atmosphere longer (14210.65 \pm 2676.63 tonnes from $104.88 \pm 15.14$ tons at $\mathrm{p}<0.001)$, gaseous and liquid $(381767.50 \pm 31927.93$ tonnes compared to $8504.53 \pm 1576.76$ tons at $\mathrm{p}<0.001)$ in Purovskiy area compared to Ustpurovsk -Tazovskiy geocryological region.

Been calculated concentration of pollutants in the water object control section (Cc.s., $\mathrm{mg} / \mathrm{l})$ and maximum ground concentration of harmful substances in the air (Cmax, $\mathrm{mg} / \mathrm{m} 3)$ (Table 2).

The concentration of pollutants in the water control zone was significantly greater in Purovskiy geocryological area compared to Ustpurovsk-Tazovskiy-over for the following substances: synthetic surfactants $(\mathrm{p}<0.05)$, phosphorus $(\mathrm{p}<0.05)$, iron $(\mathrm{p}<0.001)$, chlorides $(p<0.01)$, ammonia nitrogen $(p<0.001)$. Concentrations of pollutants in the water control zone in Ustpurovsk-Tazovskiy and Purovskiy geocryological area does not exceed the maximum permissible concentration.

The maximum surface concentration of harmful substances in the atmospheric air in Ust Purovsk-Tazovskoye geocryological region significantly more for the following pollutants: nitrogen dioxide $(\mathrm{p}<0.01)$, nitrogen oxide $(\mathrm{p}<0.05)$, sulfur dioxide $(\mathrm{p}<0.001)$. The maximum surface concentration of solids $(\mathrm{soot})(\mathrm{p}<0.001)$ and carbon monoxide $(\mathrm{p}<$ 0.001 ) was significantly lower in Purovskiy geocryological area. Is investigated the maximum surface concentration summation of substances (sulfur oxide and nitrogen dioxide), which is significantly higher in Ustpurovsk-Tazovskiy geocryological region $(0.540 \pm 0.08$ compared to $0.216 \pm 0.01$ for $p<0.001)$.

It was found exceeding the maximum surface concentration of pollutants in the atmosphere is 1.5 times MPCm.o. solids and 1.2 times MPCm.o. carbon monoxide Purovskiy geocryological area. (Table 2). This may cause the greenhouse effect in the Arctic zone. Revealed the excess of nitrogen dioxide Purovskiy and Ustpurovsk-Tazovskiy permafrost areas (1,2 and 3,0 times MPCm.o.). [24- 27]

Table 2. The concentration of pollutants in the water control zone, maximum surface concentration of harmful substances in atmospheric air and pollution standards.

\begin{tabular}{|c|c|c|c|c|c|}
\hline Substance name & $\begin{array}{l}\text { Ustpurovsk- } \\
\text { Tazovskiy }\end{array}$ & Purovskiy & $\begin{array}{l}\text { The criteria } \\
\text { used to } \\
\text { calculate }\end{array}$ & $\begin{array}{l}\text { The value of } \\
\text { the criterion }\end{array}$ & $\begin{array}{l}\text { Hazard } \\
\text { Class }\end{array}$ \\
\hline \multicolumn{6}{|c|}{ The concentration of pollutants in the water of control zone: } \\
\hline $\begin{array}{l}\text { Synthetic surface- } \\
\text { active agents } \\
\text { (surfactants), }[\mathrm{mg} / \mathrm{l}]\end{array}$ & $\begin{array}{l}0.000001409 \pm \\
0.00000035\end{array}$ & $\begin{array}{l}0.000003963 \pm \\
0.0000011 *\end{array}$ & MPCd.d. & 0.5 & 3 \\
\hline $\begin{array}{l}\text { Total phosphorus, } \\
{[\mathrm{mg} / \mathrm{l}]}\end{array}$ & $\begin{array}{l}0.000008808 \pm \\
0.0000018\end{array}$ & $\begin{array}{l}0.000020951 \pm \\
0.0000051 *\end{array}$ & MPCd.d. & 0.0001 & 1 \\
\hline Iron, $[\mathrm{mg} / \mathrm{l}]$ & $\begin{array}{l}0.000013036 \pm \\
0.0000039\end{array}$ & $\begin{array}{l}0.0000889 \pm \\
0.0000096^{* * *}\end{array}$ & MPCd.d. & 0.3 & 3 \\
\hline Sulfates, $[\mathrm{mg} / \mathrm{l}]$ & $\begin{array}{l}0.000352331 \pm \\
0.000035\end{array}$ & $\begin{array}{l}0.001132492 \pm \\
0.000566\end{array}$ & MPCd.d. & 500 & 4 \\
\hline Chloride, $[\mathrm{mg} / \mathrm{l}]$ & $0.00035 \pm 0,00007$ & $\begin{array}{l}0.00113 \pm \\
0.00023^{* *}\end{array}$ & MPCd.d. & 350 & 4 \\
\hline $\begin{array}{l}\text { Nitrogen ammonium, } \\
{[\mathrm{mg} / \mathrm{l}]}\end{array}$ & $\begin{array}{l}0.000035585 \pm \\
0.000006\end{array}$ & $\begin{array}{l}0.00061664 \pm \\
0.000094 * * *\end{array}$ & MPCd.d. & 2.0 & 3 \\
\hline Nitrates, $[\mathrm{mg} / \mathrm{l}]$ & $\begin{array}{l}0.000266009 \pm \\
0.000075\end{array}$ & $\begin{array}{l}0.00029558 \pm \\
0.000144\end{array}$ & MPCd.d. & 45 & 3 \\
\hline Nitrite, $[\mathrm{mg} / \mathrm{l}]$ & $\begin{array}{l}0.000003875 \pm \\
0.0000007\end{array}$ & $\begin{array}{l}0.0000436 \pm \\
0.0000254\end{array}$ & MPCd.d. & 3.3 & 2 \\
\hline
\end{tabular}


The maximum surface concentration of harmful substances in atmospheric air:

\begin{tabular}{|c|c|c|c|c|}
\hline $\begin{array}{l}\text { Nitrogen dioxide, } \\
{\left[\mathrm{mg} / \mathrm{m}^{3}\right]}\end{array}$ & $0.600 \pm 0,1$ & $0.240 \pm 0.01^{* *}$ & MPCm.o. & 0.20 \\
\hline $\begin{array}{l}\text { Nitrogen oxide, } \\
{\left[\mathrm{mg} / \mathrm{m}^{3}\right]}\end{array}$ & $0.052 \pm 0,01$ & $0.031 \pm 0.001 *$ & MPCm.o. & 0.40 \\
\hline $\begin{array}{l}\text { Carbon (soot), } \\
{\left[\mathrm{mg} / \mathrm{m}^{3}\right]}\end{array}$ & $0.049 \pm 0,007$ & $\begin{array}{l}0.225 \pm \\
0.04 * * *\end{array}$ & MPCm.o. & 0.15 \\
\hline $\begin{array}{l}\text { Sulfur dioxide, } \\
{\left[\mathrm{mg} / \mathrm{m}^{3}\right]}\end{array}$ & $0.025 \pm 0,003$ & $\begin{array}{l}0.009 \pm \\
0.0004 * * *\end{array}$ & MPCm.o. & 0.50 \\
\hline $\begin{array}{l}\text { Carbon monoxide, } \\
{\left[\mathrm{mg} / \mathrm{m}^{3}\right]}\end{array}$ & $1.216 \pm 0,21$ & $6.00 \pm 0.69^{* * *}$ & MPCm.o. & 5.00 \\
\hline Methane, $\left[\mathrm{mg} / \mathrm{m}^{3}\right]$ & $0.899 \pm 0,21$ & $1.379 \pm 0.14$ & OEL & 50 \\
\hline \multicolumn{5}{|c|}{ Groups of substances that have the combined harmful effects: } \\
\hline $\begin{array}{l}\text { Nitrogen dioxide, } \\
\text { sulfur dioxide }\end{array}$ & $0.540 \pm 0,08$ & $\begin{array}{l}0.216 \pm \\
0.01 * * *\end{array}$ & Cce & 1.6 \\
\hline
\end{tabular}

MPCd.d. - maximum permissible concentration of domestic and drinking water; MPCm.o. maximum permissible concentration of maximum one-time; OEL - occupational exposure limits; Cce - the combined effect of the coefficient; * - reliability of differences $(*-p<0.05 ; * *-p<0.01 ; * *$ $\mathrm{p}<0.01)$.

The effect of incomplete summation possess nitrogen dioxide, sulfur dioxide. Exceeding them in Ustpurovsk-Tazovskiy geocryological region was 2.7 MPCm.o. in Purovskiy - 1.08 MPCm.o. Majorants all the considered pollutants and summation group in Ustpurovsk-Tazovskiy geocryological region was 3 MPCm.o. in Purovskiy - 1.5 MPCm.o.

\subsection{The climatic conditions of the permafrost zone Purovskiy district of Yamalo-Nenets Autonomous region}

One of the most important characteristics is the climate temperature. It has a direct impact on humans, animals, plants, the work of various mechanisms and choice of materials, special technologies of production processes. From the temperature dependent freezing and/or thawing permafrost [22, 28]. Comparative analysis of temperature conditions Ustpurovsk-Tazovskiy and Purovskiy permafrost areas is presented in Table 3. It was found that the average temperature in the $13 \mathrm{p} . \mathrm{m}$., the average minimum temperature, maximum air temperature authentically higher in Purovskiy geocryological area. It was calculated the difference between the maximum and the absolute minimum temperature for the year as a whole in the permafrost areas of data. It was found that in Purovskiy geocryological area for the year as a whole $(76,64 \pm 0,95$ compared to 72,56 \pm 0.65 for $\mathrm{p}<0.01)$ air temperature variation bigger than in Ustpurovsk-Tazovskiy geocryological region. Table 3.

Table 3. Temperature characteristics of geological areas.

\begin{tabular}{lll}
\hline Substance name & Ustpurovsk-Tazovskiy & Purovskiy \\
\hline The annual air temperature, $\left[{ }^{\circ} \mathrm{C}\right]$ & $-7.05 \pm 1.40$ & $-5.51 \pm 0.40$ \\
The average temperature at the $13.00 \mathrm{p} . \mathrm{m} .,\left[{ }^{\circ} \mathrm{C}\right]$ & $-7.03 \pm 0.44$ & $-2.75 \pm 0.75^{* *}$ \\
The average minimum temperature, $\left[{ }^{\circ} \mathrm{C}\right]$ & $-12.75 \pm 0.37$ & $-10.19 \pm 0.40^{* *}$ \\
The absolute minimum air temperature, $\left[{ }^{\circ} \mathrm{C}\right]$ & $-45.98 \pm 0.54$ & $-47.74 \pm 0.93$ \\
The maximum air temperature, $\left[{ }^{\circ} \mathrm{C}\right]$ & $26.57 \pm 0.30$ & $29.09 \pm 0.49^{* *}$ \\
The amplitude of the vibrations of air & $72.56 \pm 0.65$ & $76.64 \pm 0.95^{*}$ \\
temperature over the year as a whole, $\left[{ }^{\circ} \mathrm{C}\right]$ & & \\
\hline
\end{tabular}


* - reliability of difference $(*-\mathrm{p}<0.01 ; * *-\mathrm{p}<0.001)$.

Correlation analysis revealed connection between the content of iron, chloride, nitrate, nitrite in the wastewater and maximum air temperature $(\mathrm{r}=0.800$ for $\mathrm{p}<0.01 ; \mathrm{r}=0.780$ for $\mathrm{p}<0.01 ; \mathrm{r}=0.660$ for $\mathrm{p}<0.05 ; \mathrm{r}=0.730$ for $\mathrm{p}<0.05$ respectively). The accumulation of iron, chloride, nitrate, nitrite in wastewater contributes to waterlogging and eutrophication and accumulation of heat. Overgrowing water bodies and soil the permafrost zone causes climate warming and enhances the environmental risks [25].

\subsection{Correlation relationship between climate and cryological features of natural and disturbed soils of the Central geocryological zone}

In the process of technogenesis being destroyed natural environment. Occurs degradation of permafrost soils. It was found that the correlation of mean monthly air temperature with humidity weighting the seasonally thawing layer (STL) of permafrost soils is dependent on their status. Correlation relationships of average monthly air temperature with humidity weight STL of natural (undisturbed) soil visible in the winter season to the soil depth of 0.6 $\mathrm{m}$. $(\mathrm{r}>0.7)$. In autumn and spring seasons - to the soil depth of $0.7 \mathrm{~m}$. At the soil depth $0.85 \mathrm{~m}$ correlations disappear. The loss of correlations at the soil depth $0.85 \mathrm{~m}$. is associated with the process of thawing soils. Permafrost soils are confining layer and prevent vertical water filtration, drainage area. Formed suprapermafrost the surface water.

Due to the active development of oil and gas fields of the northern territories appear disturbed soil. In this case, correlations between the of average monthly air temperature and humidity weight STL of soil in the winter season were in direct proportion to the depth of $0.85 \mathrm{~m}$. In the spring and autumn seasons - to a depth of $1.1 \mathrm{~m}$. The presence of correlations at a depth of $0.85 \mathrm{~m}$. in disturbed soils indicates that thawing permafrost occurs to a greater depth than in natural soils. This shows the influence of anthropogenic factors on the biosphere of the Far North, in particular on the soil.

\section{Conclusions}

In the coming years the Russian sector of the Arctic will continue to play a leading role in the extraction of gas and oil. Main gas base of the country is remaining YaNAO [4]. Environmental problems of the Russian Arctic have an impact on the ecological situation in the region and the world at large.

In considering the quality of water bodies it has been revealed that the concentrations of pollutants in the water control zone in Ustpurovsk-Tazovskiy and Purovskiy permafrost areas do not exceed the maximum permissible concentration. Excess of solids in the atmosphere (carbon black) by 1,5 times MPCm.o. and by 1,2 times MPCm.o carbon monoxide in Purovskiy geocryological area. The content of nitrogen dioxide exceeded in Purovskiy geocryological area by 1, 2 times MPCm.o. in Ustpurovsk-Tazovskiy permafrost areas by 3,0 times MPCm.o.

The pollution of the atmosphere and water bodies by pollutants is accompanied by an increase in ambient temperature. There is a degradation of permafrost. The nature of the degradation of permafrost is also dependent on technogenic activities in the region. Climatic conditions associated with cryogenesis of the natural and disturbed soils of the Central geocryological zone. There are pronounced manifestations of thermal degradation of the permafrost zone in some northern areas of the Russian Arctic.

Comprehensive study of anthropogenic factors, climatic and geocryological conditions of the Far North insufficient attention is given. Scientific evidence scattered. The main tasks in ensuring the environmental safety of the Russian Arctic are: 
- monitoring of the environment in the Arctic region;

- assessment of the environmental impact of economic activities;

- development and introduction of new techniques, technologies and materials adapted to the climatic conditions of the Arctic;

- reducing emissions of pollutants into the air, waste water discharge into water bodies through the introduction of resource-saving technologies in enterprises;

- compliance with the rules environmental protection, industrial safety and labor protection;

- rational usage of natural resources and energy, the constant optimization of their consumption;

- introduction of non-waste and low-waste technologies.

\section{Acknowledgements}

This work was supported by the grant of the RAS Presidium "Search basic research in support of development the Arctic zone of the Russian Federation" and the international grant RFFR and HIARC «Anthropogenic heat island in the Arctic - a window into the future regional climate conditions, ecosystems and society» (№ 15-55 -71004).

\section{References}

1. N.L. Mamaeva, S.A. Petrov, Oil \& Gas, 5, 148-152 (2015)

2. N.L. Mamaeva, S.I. Kvashnina, Oil \& Gas, 5, 123 - 125 (2011)

3. V.P. Melnikov, D.S. Drozdov, Arctic Subarctic: mosaic, contrast, variation Cryosphere: proceedings of the international conference, 243-246 (2015)

4. "About the environmental situation in the Yamal-Nenets Autonomous District in 2012." (Salekhard, 2013)

5. Arctic Monitoring and Assessment Programme (AMAP): Black cardon and ozone as Arctic climate forcers (Oslo, 2015)

6. N.L. Mamaeva, S.I. Kvashnina, S.A. Petrov, Oil \& Gas, 4, 119 - 122 (2011)

7. N.L. Mamaeva, S.A. Petrov, Oil \& Gas, 99-104 (2015)

8. V.P. Melnikov, D.S. Drozdov, G.V. Malkova, Geology and Exploration, 6, 75-82 (2009)

9. N.L. Mamaeva, S.A. Petrov, Tyumen state university herald, 6, 122 - 127 (2013)

10. Arctic Monitoring and Assessment Programme (AMAP): Snow, Water, Ice and Permafrost in the Arctic (SWIPA): Climate Change and the Cryosphere (Oslo, 2011)

11. E.D. Ershov, "Geocryology USSR. Western Siberia" (Nedra, Moscow, 1989)

12. Arctic Monitoring and Assessment Programme (AMAP): Human Health in the Arctic (Oslo, 2009)

13. S.I. Larin, "Atlas of the Yamalo-Nenets Autonomous District, Yamalo-Nenets District Administration" (Tyumen, 2004)

14. A.N. Agryzin, "Statistical Yearbook (1990 - 2003)", Part VII (II) (Tyumen, 2004)

15. A.N. Agryzin, "Environmental Protection in the Tyumen Region (1998 - 2003)" (Tyumen, 2004)

16. A.N. Agryzin, "Environmental Protection in the Tyumen Region (2002 - 2006)" (Tyumen, 2007)

17. "Method of calculation of maximum permissible discharges (MPD) substances in water bodies with wastewater," (VNIIVO, Kharkiv, 1990) 
18. "Guidelines on the calculation, regulation and control of polluting emissions of substances in atmospheric air (ext. And Revised)" (JSC "SRI Atmosphere», St. Petersburg, 2012)

19. OND - 86. "Methods for calculating concentrations in the air of harmful substances contained in industrial emissions" (Gidrometeoizdat, Leningrad, 1987)

20. Information on: http://eco-c.ru/products/emission.

21. A.A. Shumanova, "Climatological Handbook of the USSR", Issue 17, meteorological data for some years, Part I: Temperature, Part II: Precipitation, Part III: Snow cover, (Leningrad Hydrometeorological Publishing House, Leningrad, 1956)

22. Information on: http://meteo.infospace.ru

23. A.V. Pavlov, "Monitoring of permafrost zone", (Acad. Publishing house "Geo", Novosibirsk, 2008)

24. Arctic Monitoring and Assessment Programme (AMAP): Human Health in the Arctic (Oslo, 2009)

25. GN 2.1.5.1315-03 GN 2.1.6.2309-07

26. Information on:

http://base.consultant.ru/cons/cgi/online.cgi?req=doc;base=LAW;n=98704

27. A.I. Sysina "List and codes of materials, polluting atmospheric air," Research Institute for Atmospheric Air Protection (SRI Atmosphere), Research Institute of human and environmental ecology (St. Petersburg, SRI Atmosphere of 2012)

28. A.V. Pavlov, Publishing House of the University Book, 2, 274-281 (2011) 